\title{
TUJUAN PENCIPTAAN MANUSIA DAN FUNGSI LEMBAGA-LEMBAGA PENDIDIKAN
}

\section{Hasan}

STAIN Datokarama Palu, Jl. Diponegoro 23 Palu e-mail: hasanmuhammad@gmail.com

\section{Abstract}

God created all His creatures based on His might. He created human beings in the best form with combination of physics, reason, and spirituality. The experts in education have a concensus that to organize the civilization of human beings, education must be based on the proporrtional education demenstions, namely the balance between the physics and the spituality.

شيئـا لا ننكر بأنّ الله خلق جميـع الخلق بقو ته وقدرته لا ريب, وخلق الإ

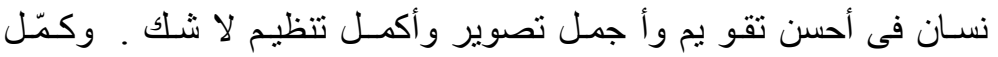

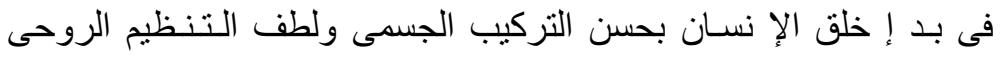

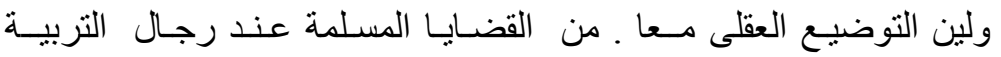

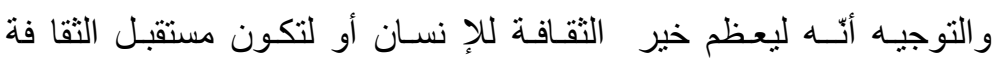
البشرية كلها خيرا إن أمكن, لا بـد من الإِ عتمـاد فى التر بيـة والتعليم

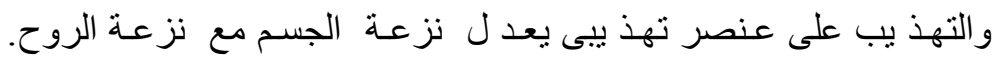

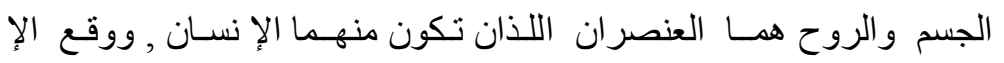

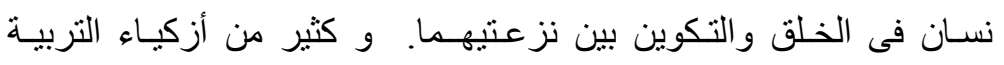

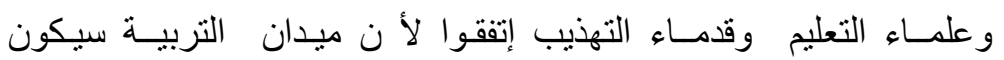
تربيــة عائليـة أو مد رسيـة أو إجتمــاعبـة وستجـرى تربيـة أولادنـا

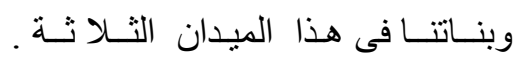

Kata Kunci: penciptaan manusia, fungsi lembaga pendidikan 


\section{PENDAHULUAN}

Pemahaman tentang manusia perupakan bagian dari kajian filsafat. Tidak mengherankan jika banyak sekali kajian atau pemikiran yang telah dicurahkan untuk membahas eksistensi manusia. Walaupun demikian, persoalan tentang manusia akan tetap menjadi misteri yang tidak kunjung terselesaikan. Hal ini antara lain, selain karena keterbatasan pengetahuan para ilmuwan untuk menjangkau segala aspek yang terdapat dalam diri manusia, juga manusia sebagai makhluk ciptaan Allah yang istimewa, agaknya memang memiliki latar belakang kehidupan yang penuh rahasia. Di samping itu, persoalan manusia sangat kompleks, sedangkan akal biasanya cenderung tidak membahas persoalan-persoalan yang kompleks.

Namun demikian, upaya untuk mempelajari manusia tidak berarti harus berhenti. Lembaran kitab suci Alquran yang memuat petunjuk tentang penciptaan manusia memuat sejumlah informasi, baik yang tersurat (jelas maknanya), maupun yang tersirat (perlu penafsiran) tentang hakikat manusia. Alquran memperkenalkan manusia melalui sekian banyak ayatnya dan memperkenalkan potensi positif dan negatif yang dimilikinya. Kepadanya diberikan petunjukpetunjuk agama agar dapat mencapai puncak tertinggi dari kemanusiaannya. Sebagai makhluk ciptaan Allah, manusia dengan segala fungsi dan peran yang harus dilakukannya, semuanya diinforamasikan dalam kitab suci. Namun demikian, informasi tersebut kadang-kadang hanya merupakan pernyataan yang memuat prinsip-prinsisp pokok, tidak dijelaskan secara rinci.

Potensi yang ada pada manusia perlu mendapat perhatian sungguh-sungguh. Perhatian tersebut diwujudkan dalam bentuk pembinaan, pembimbingan, pengarahan, dan segala bentuk upaya yang mengarahkan manusia ke arah yang lebih berdaya guna. Pendidikan merupakan salah satu dari sekian banyak upaya untuk menjadikan manusia lebih berhasil di atas pentas kehidupan sebagai hambah ciptan Allah.

\section{TUJUAN PENCIPTAAN MANUSIA}

Manusia merupakan karya Allah swt. yang paling istimewa, bila dilihat dari sosok diri, serta beban dan tanggung jawab yang diamanatkan kepadanya. Manusia satu-satunya makhluk yang 
perbuatannya mampu mewujudkan bagian tertinggi dari kehendak Tuhan yang mampu menjadi sejarah. Selain itu manusia adalah makhluk kosmis yang sangat penting, karena dilengkapi dengan semua pembawaan dan syarat-syarat yang diperlukan (Jalaluddin, 2001).

Di samping itu, ada unsur lain yang membuat manusia dapat mengatasi pengaruh dunia sekitarnya serta problema dirinya, yaitu unsur jasmani dan unsur rohani. Kedua unsur ini sudah tampak pada berbagai makhluk lain yang diberi jiwa atau roh. Akan tetapi, pada kedua unsur itu manusia dianugrahi nilai lebih, hingga kualitasnya berada di atas kemampuan yang dimiliki makhluk-makhluk lain. Dengan bekal yang istimewa ini, manusia mampu menopang keselamatan, keamanan, kesejahteraan dan kualitas hidupnya. Selain itu, manusia juga merupakan makhluk berperadaban yang mampu membuat sejarah generasinya.

Di sisi lain, manusia adalah puncak ciptaan Allah yang tertinggi. Keistimewaan ini menyebabkan manusia dijadikan khalifah atau wakil Tuhan di permukaan bumi, yang kemudian dipercaya untuk memikul amanah berupa tugas dalam menciptakan tata kehidupan yang bermoral di muka bumi (Ma'arif, 1995). Manusia diciptakan oleh Allah sebagai makhluk yang paling mulia karena kesempuraan bentuk dan kelebihan akal pikiran yang turut membedakannya dengan makhluk lainnya. Sebagai konsekwensinya, manusia dituntut untuk berbakti kepada Allah dengan memanfaatkan kesempurnaan dan kelebihan akal pikiran dan segala kelebihan lain yang telah dianugrahkan kepadanya.

Sejalan dengan kelebihan dan keistimewaan yang dimikinya itu maka Allah menegaskan bahwa sanya tujuan pokok diciptakannya manusia di alam ini adalah untuk mengenal Allah sebagai Tuhannya serta berbakti kepada-Nya. Tujuan ini ditempatkannya sebagai yang terpenting dalam hubungan dengan penciptaan manusia selaku makhluk yang diciptakan. Dengan demikian, alur kehidupan manusia yang serasi sebagai makhluk adalah apabila ia dapat mengembang tugas dan tanggung jawabnya dengan tujuan untuk berbakti kepada Sang Pencipta semesta, bukan kepentingan di luar itu.

Secara lebih jelas, keistimewaan dan kelebihan manusia, di antaranya berbentuk daya dan bakat sebagai potensi yang memiliki peluang begitu besar untuk dikembangkan. Dalam kaitan dengan 
pertumbuhan fisiknya, fungsi organ tubuh dan panca indra. Kemudian dari aspek mental, manusia dilengkapi dengan potensi akal, bakat, fantasi maupun gagasan (Shihab, 2005). Potensi ini dapat mengantar manusia memiliki peluang untuk bisa menguasai dan mengembangkan ilmu pengetahuan dan tehnologi, dan sekaligus menempatkannya sebagai makhluk berbudaya. Di samping itu, manusia juga dilengkapi unsur lain, yaitu kalbu. Dengan kalbunya ini terbuka kemungkinan manusia untuk menjadikan dirinya sebagai makhluk yang bermoral, merasakan keindahan, kenikmatan beriman dan kehadiran ilahi secara spiritual. Sebagai makhluk ciptaan Allah, manusia pada dasarnya telah dilengkapi dengan perangkat yang dibutuhkan untuk menopang tugastugas pengabdiannya. Telah cukup persyaratan yang dimiki sehingga manusia merupakan makhluk yang layak mengabdi.

\section{MANUSIA DAN PENDIDIKAN}

Hubungan manusia dengan pendidikan sebaiknya diawali dengan sebuah pertanyaan; apakah manusia dapat dididik? Ataukah manusia dapat bertumbuh dan berkembang sendiri menjadi dewasa tanpa perlu dididik? Kedua pertanyaan tersebut sejak lama telah menjadi bahan kajian para ahli pendidikan Barat, yaitu sejak zaman Yunani Kuno. Pendapat yang umumnya dikenal dalam pendidikan barat, mengenai mungkin tidaknya manusia dididik terangkum dalam tiga aliran filsafat pendidikan, yaitu nativisme, empirisme, dan konvergensi.

Menurut aliran nativisme, manusia tidak perlu dididik sebab perkembangan manusia sepenuhnya ditentukan oleh bakat yang secara alami sudah ada pada dirinya. Sedangkan menurut penganut aliran empirisme adalah sebaliknya. Perkembangan dan pertumbuhan manusia sepenuhnya ditentukan oleh lingkungannya. Dengan demikian aliran ini memandang pendidikan berperan penting dan sangat menentukan arah perkembangan manusia. Adapun aliran ketiga yaitu konvergensi yang merupakan perpaduan antara nativisme dan empirisme. Menurut mereka, manusia memiliki kemampuan dalam dirinya (bakat dan potensi), tetapi potensi itu hanya dapat berkembang jika ada pengerahan, pembinaan serta bimbingan dari luar. Perkembangan seseorang tidak hanya ditentukan oleh kemampuan potensi dan bakat yang dibawanya. Tanpa ada intervensi dari luar, 
bakat dan potensi seseorang tidak mungkin berkembang dengan baik (Marimba, 1980).

Dengan demikian menurut dia, kemampuan seseorang akan berjalan dengan baik dan dapat dikembangkan secara maksimal apabila ada sinerjisitas antara faktor dasar (potensi/bakat), ajar (bimbingan) serta kemauan dari individu itu sendiri untuk mengembangkan dirinya. Jadi, disamping faktor potensi bawaan dan bimbingan dari lingkungan, untuk mengembangkan diri, seseorang perlu didorong oleh motivasi intrinsik yaitu semacam dorongan dari dalam dirinya.

Aliran-aliran filsafat pendidikan Barat di atas menampilkan dua pandangan yang berbeda tentang hubungan manusia dengan pendidikan. Pandangan pertama menampilkan pesimisme, sedangkan aliran kedua memunculkan optimisme. Akan tetapi, tampaknya perkembangan berikutnya pandangan yang kedua lebih dominan. Manusia memang hampir tidak mungkin dapat berkembang secara maksimal tanpa intervensi pihak luar. Oleh karena itu, manusia memerlukan pendidikan (Syam, 1986).

Adapun filsafat pendidikan Islam meletakkan hubungan manusia dengan pendidikan atas dasar prinsip penciptaan, peran, dan tanggung jawab. Dalam kaitan ini manusia dilihat sebagai makhluk ciptaan Allah yang terkait oleh ketentuan-ketentuan yang telah diatur oleh Penciptanya. Dengan demikian, manusia adalah makhluk yang terikat oleh nilai-nilai ilahiyah, yaitu tatanan nilai yang telah ditetapkan oleh Penciptanya.

Manusia pada hakikatnya diciptakan untuk mengembang tugastugas pengabdian kepada Penciptanya. Agar-agar tugas dimaksud dapat dilaksanakan dengan baik, maka Sang Pencipta telah menganugrahkan kepada manusia seperangkat potensi yang dapat ditumbuhkembangkan. Potensi yang siap pakai tersebut dianugrahkan dalam bentuk kemampuan dasar, yang hanya mungkin berkembang secara optimal melalui bimbingan dan arahan yang sejalan dengan petunjuk Sang Penciptanya (Langgulung, 1986).

Mengacu kepada prinsip penciptaan ini maka menurut filsafat pendidikan Islam, manusia adalah makhluk yang berpeluang dan memiliki harapan untuk dididik. Pendidikan itu sendiri pada dasarnya adalah akvifitas sadar berupa bimbingan bagi penumbuhkembangan 
potensi ilahiyah, agar manusia dapat memerankan dirinya selaku pengabdi Allah secara tepat guna dalam kadar yang optimal. Dengan demikian, pendidikan merupakan aktivitas yang bertahap, terprogram dan berkesinambungan.

\section{FUNGSI LEMBAGA-LEMBAGA PENDIDIKAN}

Berbicara tentang lembaga pendidikan sebagai wadah berlangsungnya pendidikan, tentunya akan menyangkut masalah lingkungan di mana pendidikan tersebut dilaksanakan. UndangUndang RI No. 20 Tahun 2003 tentang Sistem Pendidikan Nasional membagi jenis pendidikan ke dalam tiga bagian yaitu: pendidikan keluarga (informal), masyarakat (nonformal), dan sekolah (formal) (Hasbullah, 2006). Setiap orang yang berada dalam lembaga pendidikan tersebut akan mengalami perubahan dan perkembangan menurut warna dan corak institusi tersebut. Berdasarkan kenyataan dan fungsi ketiga lembaga ini, Ki Hajar Dewantara menganggap ketiga lembaga pendidikan tersebut sebagai Tri Pusat Pendidikan (Barnadib, 1984). Maksudnya tiga pusat pendidikan yang secara bertahap dan terpadu mengemban suatu tanggung jawab pendidikan bagi generasi mudanya.

Ketiga penanggung jawab pendidikan ini dituntut melakukan kerja sama di antara mereka, baik secara langsung maupun tidak langsung, dengan saling menopang kegiatan yang sama secara sendirisendiri maupun bersama-sama. Dengan kata lain, perbuatan mendidik yang dilakukan oleh orang tua terhadap anak juga dilakukan oleh sekolah sebagai penguatan serta dikontrol oleh masyarakat sebagai lingkungan sosial anak.

\section{Lembaga Pendidikan Keluarga}

Bagi seorang anak, keluarga merupakan persekutuan hidup pada lingkungan keluarga, tempat di mana ia menjadi diri pribadi atau diri sendiri. Keluarga juga merupakan wada bagi anak dalam konteks proses belajarnya untuk mengembangkan dan membentuk diri dalam fungsi sosialnya. Di samping itu, keluarga merupakan tempat belajar bagi anak dengan segala sikap untuk berbakti kepada Sang Pencipta sebagai perwujudan nilai hidup yang tertinggi. Dengan demikian,n jelaslah bahwa orang pertama dan utama yang bertanggung jawab 
terhadap kelangsungan hidup dan pendidikan anak adalah orang tua (Tafsir, 1992). Fungsi lembaga pendidikan keluarga secara rinci dapat diuraikan sebagai berikut:

\section{Pemasuk pengalaman pertama}

Pengalaman hidup seorang anak berawal dari lingkungan keluarga. Hal ini harus disadari dan dimengerti oleh keluarga bahwa anak dilahirkan dalam lingkungan keluarga yang tumbuh dan berkembang sampai anak dapat hidup mandiri. Keluargalah sebagai pemasuk mengelaman pertama yang merupakan modal penting bagi perkembangan pribadi anak. Suasana pendidikan keluarga sangat penting untu diperhatikan, sebab dari sinilah keseimbangan jiwa di dalam perkembangan anak selanjutnya ditentukan.

Sebagaimana dikemukakan sebelumnya bahwa pendidikan keluarga adalah yang pertama dan utama. Disebut pertama karena kehadiran anak di dunia ini disebabkan hubungan kedua orang tuanya. Karena orang tua adalah orang dewasa maka merekalah yang harus bertanggung jawab terhadap anak. Kewajiban orang tua tidak hanya memelihara eksistensi anak untuk menjadikannya kelak sebagai seorang pribadi, tetapi juga memberikan pendidikan kepada anak sebagai individu yang tumbuh dan berkembang. Dan disebut utama karena orang tua bertanggung jawab atas pendidikan anak. Hal ini memberikan pengertian bahwa seorang anak dilahirkan dalam keadaan tidak berdaya, dalam keadaan penuh ketergantungan dengan orang lain, tidak mampu berbuat apa-apa, bahkan tidak mampu menolong dirinya sendiri.

Oleh karena itu, orang tualah yang akan memberikan corak yang dikehendaki bagi anaknya. Kenyataan tersebut menunjukkan bahwa kehidupan seorang anak pada saat itu benar-benar bergantung kepada kedua orang tuanya. Orang tua harus memberikan sebanyak mungkin contoh dan teladan yang positif bagi anak. Ucapan dan tingkah laku yang ingin dilakukannya kepada anak seharusnya diseleksi dan disaring secara cermat.

\section{Penjamin kehidupan emosional anak}

Suasana di dalam keluarga merupakan suasana yang meliputi rasa cinta dan simpati yang sewajarnya, suasana tenteram dan suasana percaya-mempercayai. Untuk itulah melalui pendidikan keluarga ini, kehidupan emosional atau kebutuhan akan rasa kasih sayang dapat 
dipenuhi atau dapat berkembang dengan baik. Hal ini dikarenakan adanya hubungan darah antara pendidik (orang tua) dengan peserta didik (anak), dan hubungan tersebut didasarkan atas rasa cinta kasihsayang yang murni.

Kehidupan emosional anak merupakan salah satu factor yang terpenting dalam membentuk pribadi seseorang. Berdasarkan penelitian, terbukti adanya kelainan-kelainan di dalam perkembangan pribadi individu yang disebabkan oleh kurang berkembangnya kehidupan emosional ini secara wajar (Hasbullah, 2006).

\section{Penanam dasar pendidikan moral}

Keluarga juga berfungsi sebagai peletak pertama dasar-dasar moral bagi anak, yang biasa tercermin dalam sikap dan prilaku orang tua sebagai teladan yang dapat dicontoh oleh anak. Dalam hal ini Ki Hajar Dewantara menyatakan sebagaimana yang dikemukakan oleh Soewarno (1985) bahwa rasa cinta, rasa bersatu dan lain-lain perasaan dan keadaan jiwa yang pada umumnya sangat berfaedah untung berlangsungnya pendidikan, terisitmewa pendidikan budi pekerti, terdapatlah di dalam hidup keluarga dalam sifat yang kuat dan murni, sehingga tak dapat pusat-pusat pendidikan lainnya menyamainya.

Biasanya tingkah laku, cara berbuat, dan cara berbicara seseorang akan ditiru oleh anak. Teladan ini akan melahirkan gejala identifikasi positif, yaitu penyamaan diri dengan orang yang ditiru, hal ini penting sekali dalam rangka pembentukan kepribadian. Segala nilai yang dikenal anak akan melekat dan terpatri dalam jiwanya. Cara ini merupakan salah satu proses yang ditempuh anak dalam mengenal nilai dan moral.

\section{Peletak dasar-dasar keagamaan}

Keluarga sebagai lembaga pendidikan pertama dan utama, di samping sangat menentukan dalam penanaman dasar-dasar moral, yang tak kala pentingnya adalah berperan besar dalam proses internalisasi dan transpormasi nilai-nilai keagamaan ke dalam pribadi anak.

Masa anak-anak adalah masa yang paling baik untuk menaburkan dasar-dasar hidup beragama. Dalam hal ini tentu saja terjadi dalam keluarga. Anak-anak seharusnya dibiasakan ikut serta ke 
mesjid bersama-sama orang tuanya untuk melaksanakan salat lima waktu, mendengarkan khutbah, ceramah-ceramah keagamaan. Kegiatan seperti ini besar sekali pengaruhnya terhadap kepribadian anak (Subrata, 1983). Kenyataan membuktikan bahwa anak yang semasa kecilnya tidak mengetahui hal-hal yang berhubungan dengan hidup keagamaan, tidak pergi bersama-sama orang tua ke mesjid atau tempat ibadah untuk melaksanakan ibadah, mengakibatkan anak, setelah dewasa, tidak ada sama sekali perhatian terhadap kehidupan keagamaan. Oleh karena itu, kehidupan dalam keluarga hendaknya diciptakan dalam suatu kondisi dan suasana agamis agar dapat membentuk kepribadian yang baik bagi anak.

\section{Lembaga Pendidikan Sekolah}

Pada dasarnya pendidikan di sekolah merupakan bagian dari pendidikan dalam keluarga, yang sekaligus juga merupakan lanjutan dari pendidikan dalam keluarga. Di samping itu, kehidupan di sekolah adalah jembatan bagi anak yang menghubungkan kehidupan dalam keluarga dengan kehidupan dalam masyarakat kelak.

Pendidikan sekolah yang dimaksud di sini adalah pendidikan yang diperoleh di sekolah secara teratur, sistimatis, bertingkat dan dengan memenuhi syarat-syarat yang jelas dan ketat, mulai dari Taman Kanak-Kanak sampai ke Perguruan Tinggi (Barnadib, 1986a).

Ada beberapa krateristik proses pendidikan yang berlangsung di sekolah di antaranya adalah:

- pendidikan diselenggarakan secara khusus dan dibagi atas jenjang yang memiliki hubungan hirarkis;

- usia peserta didik di suatu jenjang pendidikan relatif homogen;

- waktu pendidikan relatif lama sesuai dengan program pendidikan yang harus diselesaikan;

- materi atau isi pendidikan lebih banyak bersifat akademis dan umum.

- adanya penekanan tentang kualitas pendidikan sebagai jawaban atas kebutuhan di masa yang akan datang (Tanlain dkk., 1989).

Sebagai lembaga pendidikan formal, sekolah yang lahir dan berkembang secara efektif dan efesien dari dan oleh masyarakat, merupakan perangkat yang berkewajiban memberikan pelayanan kepada masyarakat dalam mendidik warga Negara. Sekolah dikelolah 
secara formal, hierarkis dan kronologis yang berhaluan pada falsafah dan tujuan pendidikan nasional. Kenyataan ini menunjukkan bahwa sebagian besar pembentukan kecerdasan, sikap, dan minat sebagai bagian dari pembentukan kepribadian, dilaksanakan oleh sekolah. Suwarno (1985) mengemukakan bahwa fungsi sekolah adalah sebagai berikut:

- menaburkan benih kecerdasan berpikir serta menyuguhkan dasardasar pengetahuan sebagai modal awal untuk memasuki suasana kemandirian. Fungsi sekolah dalam pendidikan intelektual disamakan dengan fungsi keluarga dalam penanaman awal nilai moral;

- spesialisasi, di antara ciri semakin meningkatnya kemajuan masyarakat ialah semakin bertambahnya diferensiasi dalam tugas kemasyarakatan dan lembaga sosial yang melaksanakan tugas tersebut. Sekolah memiliki fungsi sebagai lembaga yang spesialisasinya dalam bidang pendidikan dan pengajaran;

- efesiensi, kehadiran seolah adalah sebagai lembaga sosial yang mengkhususkan diri di bidang pendidikan dan pengajaran sehingga peleksanaan pendidikan dan pengajaran dalam masyarakat menjadi lebih efisien, baik dari segi waktu dan dana apalagi lagi dari segi kemampuan;

- sosialisasi, tidak diragukan lagi peran yang dimainkan oleh sekolah sebagai lembaga yang melakukan proses pembentukan dan caracara bermasyarakat, proses membantu perkembangan individu menjadi makhluk sosial, makhluk yang mampu beradaptasi dengan baik di masyarakat. Hal ini sangat beralasan sebab bagaimanapun seorang anak pada akhirnya akan berada di tangah-tengah masyarakat.

Pendidikan di lingkungan keluarga dan pendidikan di sekolah harus bekerja sama. Apa yang tidak jelas di sekolah harus memperoleh penjelasan tambahan di rumah. Apabila terjadi kesenjangan informasi mengenai prilaku anak, atau terjadi kesukaran pada anak, sekolah harus mencari hubungan untuk memperoleh keterangan yang diperlukannya itu di rumah. Di sekolah dan di rumah harus tercipta suasana saling percaya. Untuk keperluan itu, para guru perlu melakukan kunjungan ke rumag-rumah siswa, sehingga memperoleh pengetahuan yang sebanyak-banyaknya mengenai peserta didik dalam 
pengetahuan dan lingkungan kehidupannya. Guru perlu mengetahui suasana hidup kependidikannya dan bagaimana pandangannya terhadap perlunya pendidikan bagi putra dan putrinya. Melalui cara demikian guru akan memperoleh petunjuk yang berharga yang dapat digunakan di lingkungan sekolah.

\section{Lembaga Pendidikan Masyarakat}

Masyarakat diartikan sebagai sekumpulan orang yang menempati suatu daerah, diikat oleh pengalaman-pengalaman yang sama, memiliki sejumlah persesuaian dan sadar akan kesatuannya, serta dapat bertindak bersama untuk mencukupi krisis kehidupannya (Barnadib, 1986b). Dalam konteks pendidikan, masyarakat merupakan lembaga ketiga setelah keluarga dan sekolah. Pendidikan yang dialami oleh peserta didik dalam masyarakat ini, telah mulai ketika anak-anak untuk beberapa waktu setelah lepas dari asuhan keluarga dan berada di luar area pendidikan sekolah. Dapat dipridiksi bahwa betapa besar pengaruh lembaga pendidikan tersebut terhadap anak-anak. Corak dan ragam pendidikan yang didapat seseorang dalam masyarakat sangat banyak, bisa meliputi segala bidang, baik pembentukan kebiasaankebiasaan, pemahaman, sikap dan minat, maupun pembentukan kesusilaan dan keagamaan.

Lembaga pendidikan yang dalam istilah Undang-Undang No. 20 Tahun 2003 tentang Sistem Pendidikan Nasional disebut dengan jalur pendidikan non formal ini, bersifat fungsional dan praktis yang bertujuan untuk meningkatkan kemampuan dan keterampilan kerja yang berguna bagi usaha perbaikan tarap hidupnya.

Pendidikan yang diselenggerakan oleh masyarakat atau yang dikenal dengan jalur pendidikan luar sekolah, memeliki beberapa istilah di dalam kerangka pelaksanaan pendidikannya seperti:

- Pendidikan sosial ialah pendidikan yang diusahakan dengan sengaja di dalam masyarakat untuk mendidik individu dalam lingkungan sosial, supaya bebas dan bertanggung jawab menjadi pendorong ke arah perubahan seperti pendidikan di yayasanyayasan sosial. 
- Pendidikan masyarakat ialah tindakan atau pengaruh yang kadangkadang mengenai seluruh rakyat, tetapi biasanya khusus mengenai rakyat lapisan bawah.

- Pendidikan luar sekolah ialah pendidikan yang dilakukan di luar sistem persekolahan biasa, penekanannya pada pendidikan yang berlangsung di luar sekolah seperti kursus-kursus keterampilan.

- Pendidikan non formal, dan lain-lain (Hasbullah, 2006).

Jalur pendidikan ini memiliki kekhususan tersendiri antara lain adalah:

- waktu pelaksanaanya di tempatkan di luar jam sekolah

- pesertanya direkrut dari mereka yang putus dari sekolah formal

- bentuk pendidikannya tidak berjenjang, dan programnya berjangka singkat

- isi pendidikannya bersifat praktis dan khusus

- ketrampilan kerja yang sangat dominan sebagai jawaban terhadap kebutuhan (Tanlain dkk., 1989).

Dalam perspektif pendidikan seumur hidup, semua orang secara potensial merupakan peserta didik dalam berbagai tahap dalam perkembangan hidupnya. Oleh karena itu yang menjadi calon untuk masuk dalam lembaga ini sangat luas dan bervareasi. Bisa saja para pesertanya berasal dari para buruh dan petani, remaja yang putus sekolah, para pekerja yang berketrampilan, para pemimpin masyarakat dan lain-lain. Yang lebih menarik lagi karena tidak menggunakan acuan serta patokan usia yang masuk ke dalamnya.

Lingkungan masyarakat juga mempunyai pengaruh pendidikan anak di sekolah. Terhadap pelaksanaan pendidikan di sekolah, sekolah dan masyarakat mempunyai hubungan timbal-balik. Sekolah menerima pengaruh masyarakat, dan masyarakat dipengaruhi oleh hasil pendidikan sekolah. Menjadi tugas sekolah untuk mengenalkan kepada anak agar belajar hidup di masyarakat dan belajar memahaminya, mengenal baik dan buruknya. Dengan demikian, anak diharapkan agar memahami dan menghargai suasana masyarakatnya. Sebagian dari tujuan sekolah adalah mengantarkan anak dari dalam kehidupannya ke dalam masyarakat. Dengan demikian, pendidikan yang berlangsung dan diselenggarakan masyarakat harus menjadi penunjang dan pelengkap yang mampu untuk mengembangkan 
pengetahuan dan wawasan anak. Demikian pula hendaknya yang terjadi di lingkungan keluarga, pendidikan harus menjadi motivasi yang saling menguatkan sehingga terwujud keterpaduan antara ketiga lembaga pendidikan tersebut. Fungsi ketiga lembaga pendidikan yang dimaksud harus diusahakan agar tidak tumpang-tindih, saling melemahkan apalagi menjadi pertentangan satu dengan lainnya.

\section{PENUTUP}

Manusia diciptakan oleh Allah swt. sebagai makhluk yang paling mulia karena kesempurnaan bentuk dan kelebihan akal pikiran sebagai modal dasar untuk memikul tanggung jawab dan amanah sebagai khalifah di muka bumi. Karena keistimewaan dan kelebihan yang dimilikinya itulah maka tujuan pokok diciptakannya manusia di alam ini adalah untuk mengenal Allah sebagai Tuhannya serta berbakti kepada-Nya.

Sebagai makhluk hidup, manusia tumbuh dan berkembang secara evolusi, baik selama dalam kandungan maupun setelah lahir. Sejak kelahirannya ia berada dalam keadaan tidak mengetahui sesuatu apapun. Allah membekali manusia potensi pada pendengaran, pengelihatan, dan hati. Keberadaannya di alam raya ini termasuk makhluk tanpa daya yang tidak mungkin bisa berevolusi secara wajar dengan sendirinya, sehingga memerlukan bantuan dari luar berupa pemeliharaan, pembinaan, dan bimbingan. Ini adalah isyarat bahwa hakikat penciptaan manusia adalah ciptaan yang berpotensi mengembangkan diri melalui pendidikan.

Dalam ilmu pendidikan dikenal ada tiga macam lembaga/lingkungan pendidikan, yaitu keluarga, sekolah, dan masyarakat. Lingkungan keluarga berfungsi sebagai pendidik pertama sekaligus peletak pondasi kependidikan. Sekolah sebagai lembaga pendidikan kedua, juga merupakan bagian dan lanjutan dari pendidikan dalam keluarga. Lingkungan masyarakat juga mempunyai pengaruh dan andil terhadap pelaksanaan pendidikan dan pengajaran di sekolah.

\section{DAFTAR PUSTAKA}

Barnadib, Imam. 1984. Filsafat Pendidikan Islam. Yogyakarta: IKIP-FPKIP Gama. 
Barnadib, Imam. 1986. Pengantar Ilmu Pendidikan Sistematis. Yogyakarta: IKIP-FKIP.

Barnadib, Imam. 1986. Filsafat Pendidikan: Tinjauan Beberapa Aspek dan Proses Pendidikan. Yogyakarta: Andi Offset.

Hasbullah. 2006. Dasar-Dasar Ilmu Pendidikan. Jakarta: PT. Raja Grafindo Persada. 2006.

Jalaluddin, dkk. 1977. Filsafat Pendidikan. Jakarta: Gaya Media Pratama.

Langgulung, Hasan. 1986. Manusia dan Pendidikan. Jakarta: Al Husna.

Ma'arif, Syafi'i. 1995. Islam dan Kenegaraan. Jakarta: P3ES.

Marimba, D. Ahmad. 1980. Pengantar Filsafat Pendidikan Islam. Bandung: Al Ma'rif.

Subrata, Suryo. 1983. Beberapa Aspek Dasar Kependidikan. Jakarta: Bina Aksara.

Suwarno. 1985. Pengantar Umum Pendidikan. Jakarta: Aksara Baru.

Shihab, M. Quraish. 2005. Dia Dimana-Mana: Tangan Tuhan di Balik Setiap Fenomena. Cet. II. Jakarta: Lentera Hati.

Syam, Mohammad Noor. 1986. Filsafat Kependidikan dan Dasar Filsafat Kependidikan Pancasila. Surabaya: Usaha Nasional.

Tafsir, Ahmad. 1992. Metodik Khusus Pendidikan Islam. Bandung: Remaja Rosdakarya.

Tanlain, Wens dkk. 1989. Dasar-Dasar Ilmu Pendidikan. Jakarta: Gramedia. 